\title{
Spectres of Cecil Rhodes at the University of Cape Town'
}

\author{
Nick Shepherd
}

\section{After the \#Fall}

On 9 March 2015, in an event choreographed for the press, Chumani Maxwele, a student at the University of Cape Town (UCT), threw the contents of a portapotty at a statue of Cecil Rhodes strategically located at the main pedestrian entrance to the university's upper campus. Photographs of the moment were widely circulated. Maxwele wears a pink construction helmet, possibly referencing the red helmets of the populist political party the Economic Freedom Fighters (EFF) and sandwich boards with the slogan 'Exhibit: White Arrogance @ UCT' (Shepherd 2020). The act of throwing human faeces is an established mode of protest in the Western Cape. Anthropologist Steven Robins has written with insight and humour about the 'poo protests' deployed by the urban poor as a means of protesting the slow pace of service delivery under the presidency of Jacob Zuma (Robins 2013, 2014). In Cape Town, this has manifested itself in the lack of waterborne sewerage in many of the city's informal settlements, forcing residents to rely on an unsanitary and unsafe 'bucket system'. Poo protests have taken many forms, including pelting passing motorists on the city's N2 motorway and dumping buckets of shit on the driveways and doorsteps of householders in the city's wealthy suburbs. As political theatre, poo protests tap into multiple taboos, including Xhosa notions of hygiene, civility and respect, together with their opposite, gross disrespect and insult directed against another person (Robins 2013, 2014) (Figure 3.1).

Lingering with the moment, we can further annotate it in the following way: the statue of Rhodes was sculpted by the British medalist and figurative sculptor Marion Walgate, wife of the architect Charles Walgate who played a role in the design of the upper campus of UCT following the death by suicide of its principal architect J. M. Solomon (Phillips 1993). The statue was commissioned by then Governor General, the Earl of Clarendon, and paid for by the Rhodes National South African Memorial Committee. Dedicated in 1934, it shows Rhodes seated in the pose of Auguste Rodin's The Thinker (Le Penseur), although slightly more upright than the original. His right elbow rests on his thigh, and his head-which is slightly 


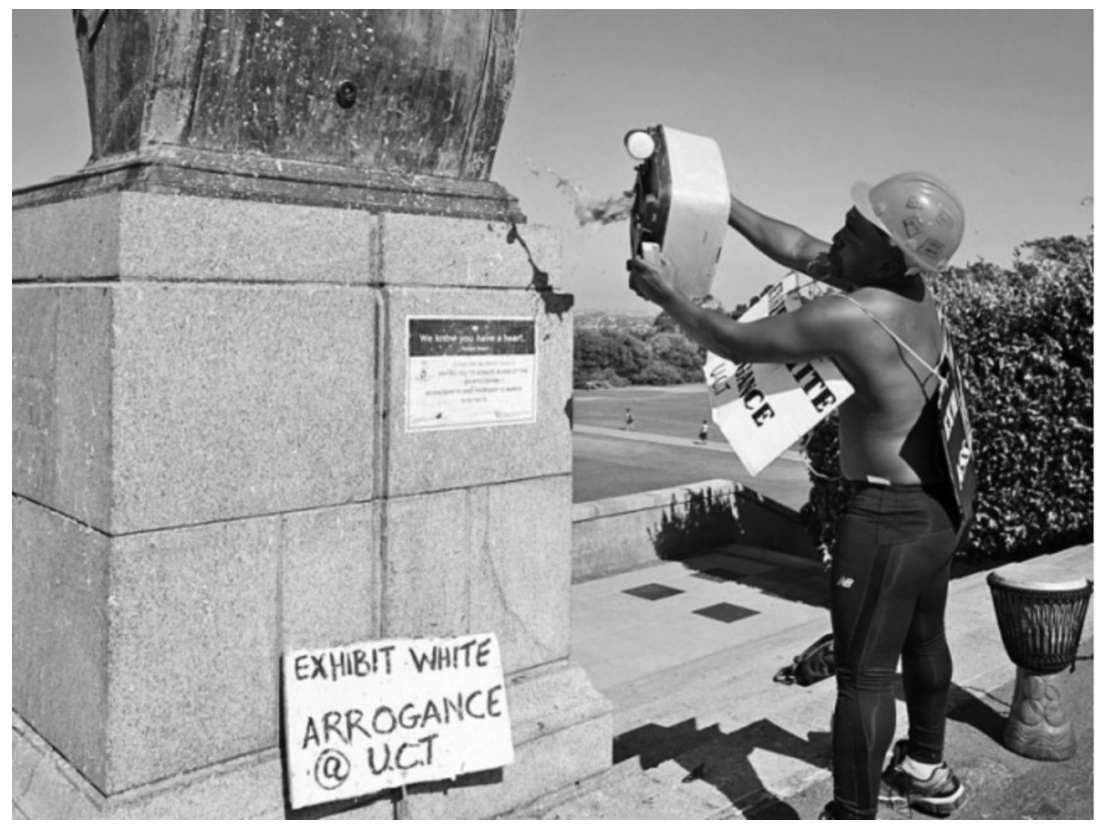

Figure 3.I Chumani Maxwele and the Rhodes statue, 9 March 2015. Photograph widely circulated on social media. This version accessed from the UCT: Rhodes Must Fall Facebook group, 13 May 2020.

overscale - rests on his right fist. His left hand dangles over the edge of the chair or throne and is loosely clasped around a roll of papers. His gaze and the full force of his attention is directed forwards, towards the distant mountains of the 'Hottentots Holland'. Walgate's statue stood on a substantial plinth of granite blocks (it was the plinth rather than the statue itself that was splashed with faeces). Inscribed on the plinth are the words 'Cecil John Rhodes 1853-1902', and below this, some lines from Rudyard Kipling's poem $A$ Song of the Cities (1893): 'I dream my dream by rock and heath and pine/ Of Empire to the northward. Ay, one land/From Lion's Head to Line' (Twidle $2012,92)$. In the figurative staging of the scene, Rhodes is understood to be gazing north towards Africa (in fact, he gazes a few points south of due east). The statue was originally located approximately 100 metres further down the slope at the entrance of the upper campus proper. With the construction of the motorway bisecting the university's upper and middle campuses in 1962 (Rhodes Drive, which leads to Settlers Way), it was relocated to the position where Maxwele encountered it, at the intersection of the lower ring road and the university's Jameson steps (Shepherd 2020) (Figure 3.2).

Maxwele's action led to a month-long protest and the formation of the student-led social movement \#RhodesMustFall (\#RMF). Initially calling for the removal of the Rhodes statue, the protest broadened to encompass 


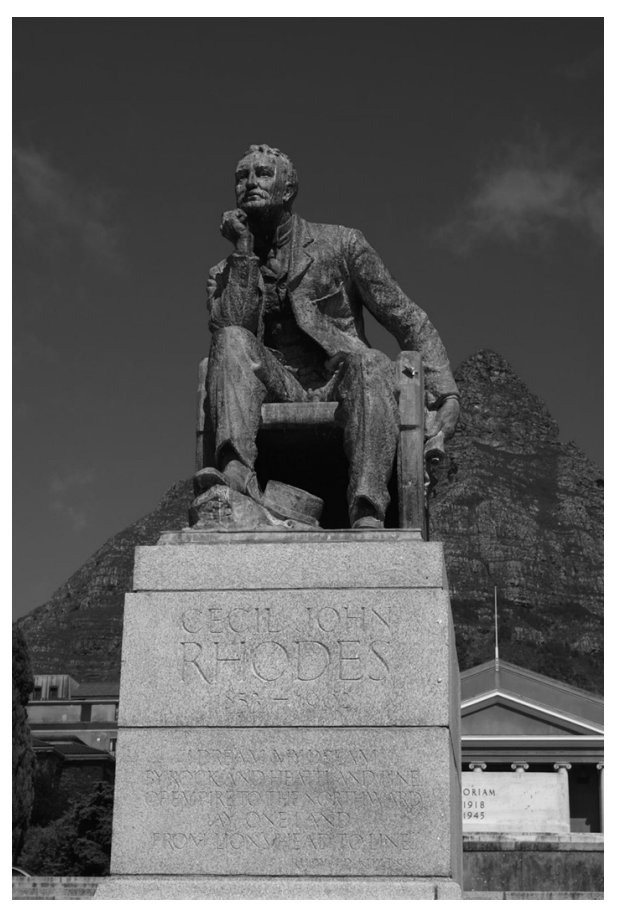

Figure 3.2 Marion Walgate's statue of Rhodes at the University of Cape Town. Photograph by Danie van der Merwe, used under Wikipedia Creative Commons licence. This file is licenced under the Creative Commons Attribution 2.0 Generic licence.

the legacies of colonialism and institutional racism at UCT and the call to 'decolonize' higher education (Nyamnjoh 2013). In the weeks that followed, \#RMF protesters marched, picketed and held mass meetings. Numerous protest action focused on the statue itself, which was graffitied, covered over with black plastic bags, and became the site of spontaneous acts of defiance and disrespect. On $20 \mathrm{March}$, \#RMF activists occupied the main administrative building of the university-Bremner Building-site of the ViceChancellor's office, which they renamed Azania House. During the occupation of Azania House, volunteers brought meals to the students, who conducted impromptu 'teach-ins'. It was during this period that student activists began to articulate the elements of \#Fallist thinking. This draws from multiple sources, chief among them historical anticolonial and antiracist thinkers and activists, such as Frantz Fanon and Bantu Steven Biko, contemporary decolonial thinkers, such as Walter Mignolo, and feminist theories of intersectionality. At the centre of these different bodies of ideas are notions of race, gender and coloniality. In the years that followed, the student activists who were part of these protests would talk about the solidarity and 
comradeship of the period of occupation (Dhlamini, personal communication, 23 May 2017; Mahapa, personal communication, 23 May 2017). On 27 March, the university's Senate voted in favour of removing the Rhodes statue. A few days later, the Council of UCT, the university's highest decision-making body, confirmed this decision. Finally, on 9 April 2015, exactly one month after Maxwele's poo protest, the statue was removed from the university campus. The South African social documentary photographer David Goldblatt captured the moment of the removal in an iconic image. A flatbed truck stands in front of the plinth. The Rhodes statue dangles in midair, suspended on the arm of a crane. A mass of onlookers surrounds the scene, many with cell phone cameras and tablets held aloft, captured by Goldblatt in the act of capturing the moment (Shepherd 2020).

There is something deeply satisfying about the fall or removal of statues when those statues are of unpopular or tyrannical figures. Such moments become allegorical in a larger sense. They speak not only of the hubris of power, but also of its fragility and the unexpected fall from grace (Shepherd 2020). Paul Maylam, Rhodes's most important recent biographer, recounts an anecdote in which Rhodes tells his friend Leander Jameson that he expects to be remembered for millennia: 'I give myself four thousand years' (Maylam $2005,12)$. As a concept, history feels abstract and ungraspable. We understand that we are caught up in it, but at the same time its connection to the particularity and detail of our own lives can be difficult to fathom. When we are present at the dramatic fall or removal of a statue, as the student activists of \#RMF were on 9 April 2015, we understand that we are part of history in the making and that, as the saying goes, 'history unfolds before our eyes'. At the same time, some important questions are left unanswered by these events. Everyone understands that an act like the removal of the Rhodes statue is a largely symbolic act, but how does it relate to, as it were, actually existing power in the world? What is the link between the symbolic act and the materiality of power? Should the removal be read as a statement of intention-a commitment to confront the legacies of Cecil Rhodes and colonialism at the university - or does it become an end in itself? And what form do these legacies take? A statue on the landscape is an obvious legacy in the sense that it draws attention to itself, but what about less obvious legacies? Do we feel confident that we would know these legacies when we see or experience them? What, precisely, are the forms taken by the coloniality of power and knowledge?

Heritage practices of symbolic restitution often target the obvious vestiges of colonialism, slavery and racism: statues, street names and so on. A starting point for my investigation in this chapter is the notion that coloniality exists as a form of deep inscription, in landscapes, in lives and in bodies of ideas and practices (Mignolo 2007, 2008, 2011, 2013; Shepherd 2020). A second starting point is the idea that the forms of this coloniality are very often hidden from us, in the sense that we see them but we do not recognize them as such. The term that I favour is a Freudian notion of disavowal: the 
disavowed object is the thing hidden in plain sight, the thing that we do not (we must not, we cannot) name, because to do so would be to be confronted by uncomfortable truths or realizations (Bass 2002; Freud 1923). So, what are some of these deeper meanings and hidden truths in the case of UCT? Besides the statue, what other kinds of legacies has Rhodes left, in the landscape, in the university as an institution and in the lives of the students and scholars who share this landscape and this institution? What does it mean to live in relation to a systematic process of disavowal?

These are big questions. In this chapter, I will begin to address some of their aspects. Taking the events of \#RMF as a starting point, I will move back through time to excavate the deeply inscribed coloniality of UCT. I am trained as an archaeologist, and what I propose here is a broadly archaeological method, perhaps as Michel Foucault would understand it: a critical tracking of genealogies, an uncovering of hidden archives and a tracing of the hidden sources of practices and ideas (Shepherd 2017). In the first part of the chapter, I go back to the period of the construction of the upper campus of UCT in the 1920s. In the second part, I revisit the 1890s and the period of Rhodes's tenure at the homestead of Groote Schuur, when he did so much to shape a memorial landscape and set in place the ideas that would frame his legacy.

Two factors make this an especially promising exercise, and one with potentially broader relevance in thinking about the nature and forms of coloniality. The first is the extraordinary degree of the historical involvement or entanglement of Cecil Rhodes with the broader landscape of UCT, along with the fact that he intervened so energetically to construct a symbolic landscape of forms. I have called this an 'exemplary landscape' in the sense that it was designed and constructed with a purpose that was partly didactic, partly the celebration of a particular kind of imperial power and partly playful - a fantasy landscape of dreams and imaginaries (Shepherd 2020). The means necessary to establish such fantasy landscapes are beyond most of us, other than on the small scale of a suburban garden or house remodeling, but for Rhodes it was not only possible but an important part of his legacy. UCT's upper and middle campuses form one part of the much larger Groote Schuur estate on the slopes of Devil's Peak, the eastern buttress of Table Mountain, which Rhodes acquired piecemeal through the 1890s (Phillips 1993). The other architectural elements of this landscape that I will discuss include the Groote Schuur manor house, the zoological garden established by Rhodes on the slopes immediately above this house and the imposing Rhodes Memorial completed in 1912. By way of spatial orientation, the Rhodes Zoo (also known as the Groote Schuur Zoo) lies on the immediate southern boundary of the UCT upper campus, while Rhodes Memorial lies on the immediate northern boundary of the university slightly higher up the slope. Together they form an ensemble of shared forms and deeply inscribed meanings.

A second factor that makes this a promising study location is the fact that, in many ways, UCT was conceived and established as an arch-colonial 
institution. No less than Rhodes's landscape of forms, it was (and is) meant to be exemplary in particular ways. The central architectural elements of the upper campus were designed as part of a single coherent project, and it is for the most part a bounded 'campus', set apart from the surrounding city. I shall address the question of what 'arch-colonial' means below. For the moment, we might note that in 2012 the British publication the Daily Telegraph named the UCT upper campus as third in a list of the ten 'most beautiful university campuses in the world' (the top two being Oxford and Harvard) (Daily Telegraph 2012). As to what criteria of beauty are at work, as with the question of the 'arch-colonial', we should leave that to the body of this work.

It feels important to establish my own position in relation to the events and contexts described here. Beginning in the mid-1980s, I was a student at UCT. From 2000 to 2017, I was a member of the academic staff of the university, based in the Centre for African Studies where I established and taught a graduate programme in Public Culture and Heritage in Africa. In 2011, I began offering a Master's course on decolonial thinking and practice, and in late 2014, I hosted Walter Mignolo in an extended seminar in the Centre for African Studies that was to become an important source for \#RMF and \#FeesMustFall (\#FMF). The story that I unfold here is one that would be familiar to students from the Centre for African Studies and formed part of my teaching at the university for many years.

The events around \#RMF were a beginning, not a complete story. It led to further protests: the \#Shackville protests against inadequate provision of student accommodation, the protest actions against artworks at UCT, the transgender initiative's protest at the Centre for African Studies Gallery, and the important national student protests of \#FeesMustFall. These events have had a seismic effect on university life and culture in South Africa, to the extent that I would argue that there is a clear 'before' and 'after'. I would argue that many of the old certainties and entitlements can no longer be taken for granted and thinking and writing 'after the \#fall' means having to centre on questions of race, gender and coloniality. Finally, this chapter situates itself as a limited exercise in thinking through the deeper meanings of the UCT after the \#fall.

\section{The temple on the hill}

The South African College, later the University of Cape Town, was founded in 1829 on a site in the centre of the city. It moved to its current location on the Groote Schuur estate in the 1920s. Two things enabled this move. The first was the terms of Rhodes's will that deeded the land for the establishment of the university. The second was a bequest of money made by Messrs. Werner and Beit, mining magnates, the so-called Werner-Beit Bequest (Phillips 1993). From the beginning, the intention was that UCT on its new site should embody the ideals of an Oxbridge institution, a kind of 'Oxbridge in Africa'. In the final design of the university this intention was manifested in details 
both great and small: the quadrangular colleges of the original men's and women's residential buildings and the stucco exteriors of the university buildings that encourage a luxuriant growth of ivy. Herbert Baker was at that time the pre-eminent South African architect, largely through his association with Rhodes and the many public buildings he had designed. Baker being unavailable, a younger architect from his studio, Joseph Michael Solomon, was commissioned to produce a design for UCT. Solomon was dispatched on a study tour of 'great universities of the world', which took him to the United States and Europe (Phillips 1993). His itinerary included the University of Virginia, whose Jefferson Rotunda formed the basis for the design of the UCT's great hall (Jameson Hall, named after Rhodes's confederate, and recently renamed Sarah Baartman Hall), an imposing structure in the neoclassical style. On his return, Solomon drew a plan for UCT that, with slight modifications, was the plan that was eventually realized in the construction of the university. Solomon's design works from a strong vertical axis and a series of cross-axes that follow the contours of the lower slopes of Devil's Peak. The vertical axis runs from the top of Devil's Peak through a small pavilion, or Summer House, constructed in the late eighteenth century, the only existing structure on the site. Arrayed along the vertical axis are the central pediment of the neoclassical façade of Jameson Hall, a series of dramatic flights of stairs that lead from level to level of the university (the Jameson Steps) and the central plaza. The cross axes take the form of a series of sweeping avenues, originally imagined as straight lines but later curved to allow for the natural contours of the site (Figure 3.3).

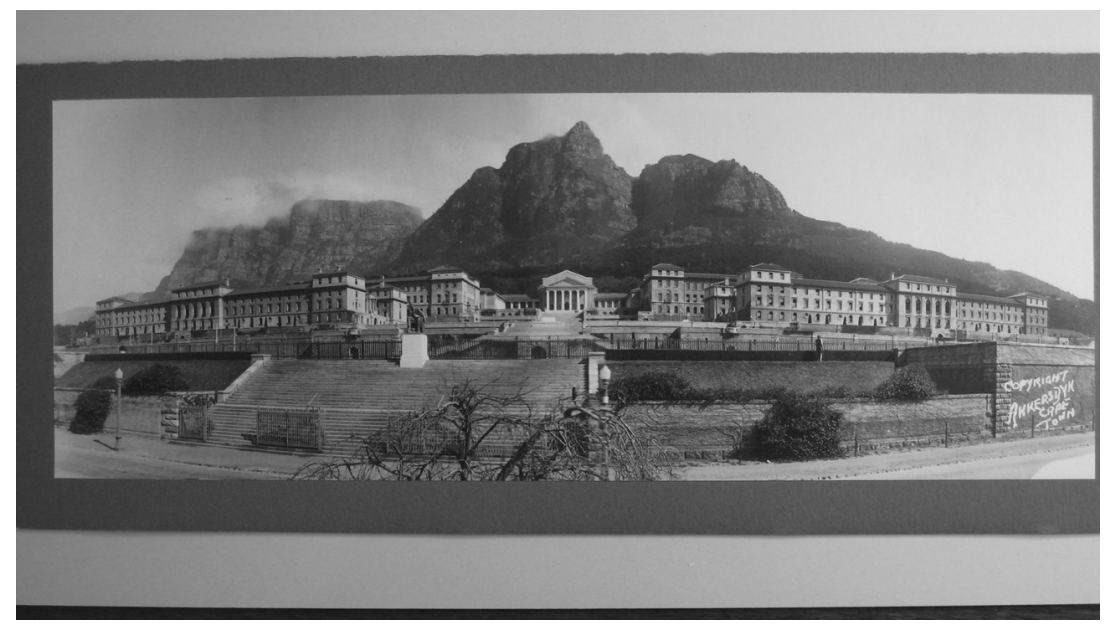

Figure 3.3 The University of Cape Town, with the Rhodes statue in its original position, slightly further down the slope. In the background, Devil's Peak. Author's photograph of the original located in the Manuscripts and Archives Department of the University of Cape Town Library. Used with permission of the University of Cape Town Library. 
In design terms, Solomon's plan makes use of two architectural tropes, both of which are common in university designs, but seldom as perfectly realized as in the case of UCT. The first is the idea of the Temple on the Hill (Shepherd 2020). The idea is that one approaches the university from the base of the mountain-Rondebosch, in this case - sweating and toiling up the lower slopes via a pathway along the central axis (the Japonica Walk), a lonely pilgrim or seeker of knowledge. After several steep climbs up the Jameson Steps one finally encounters the temple (Jameson Hall) where, figuratively, one stands with the gods and, as it were, breathes the rarefied air and thinks deep thoughts. Along the route of this pilgrimage one encounters the statue of Rhodes, himself brooding, pensive, deep in thought. The second idea manifested in Solomon's design is the idea of the site of prospect. Standing in front of Jameson Hall on the central plaza of the university one turns one's back to the mountain and looks out at the city, arrayed below in distant prospect: Rondebosch, Rosebank, Newlands and further off, Athlone and the Cape Flats. This is a kind of looking - literally an 'over-looking'which is filled with power and intention. Standing figuratively with the gods, one looks out over the busy minutiae of daily life, literally and metaphorically 'above it all'. I would argue that it is possible to understand this form of the gaze as a kind of imperial gaze, and I would further argue that the Rhodes statue itself instructed us in this form of gazing (Shepherd 2020). The pensive figure of Rhodes in his chair gazed out and over. What he gazed at is Africa, 'one land to the northward' in the words of Kipling's poem, figured by the distant peaks of the 'Hottentots' Holland' or the more proximate Cape Flats. Thus, Rhodes's statue, strategically located at the symbolic entranceway to UCT, formed a potent statement encapsulating the metaphorical thrust of the architectural design of the university and its dramatic staging on the slopes of Devils Peak. Conversely — but importantly — what might be called the imperial designs of UCT extend well beyond the single instance of the statue of Rhodes and are deeply scripted into the university's architectural fabric and the organization of space. The Temple on the Hill and the act of imperial gazing carry on, even after the removal of the statue of Rhodes. Indeed, they are part of the habitus of UCT, something that we absorb through our bodies as we inhabit and are inhabited by the space, and which we are only partially able to name.

For decades, I either walked or drove to the UCT campus, so that I feel that I too have been imprinted by this habitus, and I carry its marks as an unwilling legacy. It is certainly worth mentioning that it is mainly poorer staff and students, many of them black, who approach the university on footand would have encountered the Rhodes statue - while wealthier staff and students drive in via one of the other entrances. I suspect that it was strong emotion-rage against this habitus that gave a particular edge to the \#RMF protests and allowed students to mobilize so effectively against the statue. If we look at faces in the crowd in photographs of the events of 9 April, we see a palette of emotions: joy, glee, but also sheer relief. Of course, all of this begs 
the question: what to do about this more generalized habitus now that the Rhodes statue has gone? And does the removal of the statue mean that the imperial designs of the institution are merely more deeply veiled?

I want to take this argument one step further by linking it to questions of knowledge and epistemology. What does it mean (and what has it meant) for disciplinary knowledges at UCT when the figure of the researcher is placed above it all, and the life of the city unfolds at a distance, like the scurrying of so many ants? And further, what does it mean when this figurative positioning of the researcher in relation to their research subjects (which, after all, is not that uncommon in universities elsewhere) has taken place in the real-world historical contexts of colonialism and apartheid? I would argue that in the case of UCT this has manifested in what might be thought of as the university's state of exception. This has at least two aspects. One is the idea that the university stands apart from society and the struggles and stratagems of the people at the bottom of the mountain are not a core part of a scholar's concerns, unless they figure as data. In my own discipline, archaeology, I have argued that a common response amongst South African archaeologists in the 1970s and 1980s was to argue that the politics of apartheid was none of their concern. They understood their job to be the objective reconstruction of prehistory, untrammeled by the politics of the present (Shepherd 2003, 2007, 2015). My impression is that this kind of position was - and to an extent still is - quite widely shared across the disciplines at UCT. Numerous important interventions over the years have challenged and critiqued this aspect of UCT's state of exception. They include the interventions of political scientist Mahmood Mamdani in the late 1990s shortly after South Africa's first democratic elections as well as more recent interventions by Harry Garuba, Premesh Lalu, Njabulo Ndebele, Siona O'Connell, Xolela Mangcu and many others. Taken together, these interventions form a counter-tradition that is an enduring part of the university's legacy in and of itself.

A second aspect of this state of exception is the perception that UCT, while not quite a European institution, is also not quite an African institution - in fact, that it exists in an in-between state, not-quite-European and not-quiteAfrican (in other words, precisely, a state of exception). Once again, the Rhodes statue provided a figurative rendering of this idea. Rhodes sat with his back to the university, fronting onto the city at the bottom of the hill and the continent that lies beyond it. Behind him lies the university, and behind the university lies the mountain and the empty sea (at least figuratively). Africa in this rendering lies somewhere to the front of Rhodes ('yonder lies your hinterland'). The thin strip of territory between the mountain and the statue of Rhodes, the belt that comprises the Groote Schuur estate, is constituted as something else, a partially European world at the tip of Africa. To grasp this idea in full we need to dig deeper into the layered symbolic landscape of the Groote Schuur estate and understand a figurative world constituted not only by the grand symbolic stagings of architectural forms, but also by plants and animals. 


\section{A last little piece of Rhodesia}

In the early 1890 s, Rhodes was at the height of his influence. A remarkable career had seen him make a fortune on the diamond fields of Kimberley where he established De Beers Consolidated Mines and become Prime Minister of the Cape Colony in 1890. In 1893, he first leased, and then bought, an estate on the slopes of Devil's Peak, Groote Schuur, along with 1,500 acres of surrounding land. Groote Schuur (big barn) had been constructed as a Dutch East India Company granary in 1657 before passing into private hands in the eighteenth century. Rhodes had Groote Schuur enlarge and renovated, entrusting the task to Herbert Baker, a young architect who was to play an important role in realizing Rhodes's vision in the built environment. Baker invented a new style for the purposes, marrying aspects of Cape Dutch vernacular-like the exaggerated gables - to English Arts and Crafts style (Claassen 2009). A frieze placed over the front entrance depicts the arrival of Jan van Riebeeck in 1652 and the establishment of the Dutch settlement at the Cape.

Rhodes intended that Groote Schuur should be bequeathed to the nation as a state house and appears consciously to have incorporated British and Dutch (or Afrikaner) iconographic elements in the design. Other elements, notably the downspouts of the gutters and finials of the interior staircases, shaped like Zimbabwe birds, reference the site of Great Zimbabwe in the newly conquered territory of Southern Rhodesia (now Zimbabwe). Interestingly, the intention to bequeath Groote Schuur as a state house pre-dated both the South African War (1899-1902) and the Act of Union in 1910 that established South Africa out of a set of disparate territories, and as such it was conceived as a state house for a state not yet in existence (Shepherd 2020). From 1911 to 1994, Groote Schuur was the official residence in the Cape to 11 Prime Ministers, including the architects and perpetrators of apartheid. Significantly, when Nelson Mandela became head of state in 1994 he declined to live there, moving to a smaller house lower down the slope (Fischer n.d.).

Groote Schuur is now kept as a museum and can be visited by special application. I visited with a group of students from the Centre for African Studies in 2014. Rhodes's bedroom at the back of the house is kept as a kind of shrine. His bed faces the window, which has a view of Devil's Peak. Opposite his bed, a glass-fronted cabinet of curiosities is filled with Africana: carved wooden headrests, soapstone bowls, potsherds and stone artefacts. On top of the cabinet is one of the eight soapstone birds looted from the Great Zimbabwe site that was stolen by the hunter Willie Posselt in 1889. Against the objections of the local chief, Posselt sawed it from the column on which it was standing and sold it to Rhodes. This is the last remaining bird not to have been repatriated following the independence of Zimbabwe in 1980 and appears to have dropped from public consciousness (Mudariki 2014).

Shortly after the beginning of his tenure at Groote Schuur, Rhodes had a zoological garden established further up the slope of Devil's Peak, within 
sight of his bedroom window. Sarah Ommanney, whose beautifully curated book Lacuna: Groote Schuur Zoo (2012) constitutes the most extensive source on Rhodes's Zoo, reports that this began as a 'herbivorous menagerie' but diversified when he was given a pair of lions and a leopard. Further gifts and exchanges rapidly diversified the zoo, and 'over the years a large variety of creatures was added' (Ommanney 2012, 37): a lion cub was exchanged for a camel from a circus; a Kudu bull escaped and got into the garden of Rudyard Kipling's home on the estate; a kangaroo escaped and was caught in a leopard trap and shot by a farmer. Photographs of the zoo show, in addition to these creatures, a blue wildebeest, a crested crane, vervet monkeys, zebras and peacocks. Like many zoos, the one constructed on Rhodes's estate was made in part as a social and political statement. Rhodes collected or was given animals from throughout the British empire, thereby rendering it a miniempire of animals. It also served an important didactic function. Rhodes opened that part of his estate to the public, or at least to $a$ public - middleclass and white, by caste if not by race - in the fractured public sphere that constituted colonial society. Following his death in 1902, his will stipulated that the zoo was to be kept open to the public free of charge. The zoo 'would open every day at 9 and close again at 5 to the sound of a whistle' (Ommanney $2012,5)$. Around the time of the construction of the UCT upper campus immediately adjacent to the zoo site in the late 1920s, the original zoological garden was demolished and a larger and more ambitious zoo was laid out. Plans of the second iteration of the Groote Schuur Zoo survive. Birds and monkeys occupied the lowest levels of the zoo, while further up the slope were cages for 'large birds' and 'small animals'. The lions, king of beasts, occupied an imposing structure at the top of the slope: a deep pit-like enclosure built around a grassy knoll staged the lions against sweeping sandstone walls and the dramatic backdrop of Devil's Peak. Front-stage and back-stage zones divide the lion enclosure into an amphitheatre-like viewing area and a roofed and barred backstage area. Like the newly completed upper campus of UCT, the zoo is built around a strong central axis with a series of lateral terraces. The lion enclosure occupies an equivalent position to Jameson Hall, the great hall of the university and the cages on the terraces occupy equivalent positions to the main university buildings.

Rhodes appears to have been deeply interested in exploring the iconicity of lions, both as symbols of British empire and also in a more personal capacity (Rhodes was sometimes described as 'the lion of Africa'). The archives of the UCT Library contain the plans of an ambitious and impractical Lion House that Rhodes had Baker design around the time of the remodelling of Groote Schuur. They show a vast, colonnaded neoclassical structure - a kind of temple - through which wild African lions would be free to roam. In his 1934 biography of Rhodes, Baker writes that Rhodes had envisaged

a spacious and beautiful building: a Paestum temple was in his mind where the king of beasts would be admired in his natural strength and 
dignity. The old Roman in him pictured the beauty of lions moving through great columns, and he was quite unperturbed when warned of the sanguinary fights that would ensue. The plans did not go far. The lion-house idea receded to the back of his mind, or took place only as a smaller cage-building.

(1934, 46-7)

The Lion House is interesting as an idealized image that speaks to the relationship between Africa, a Western classical tradition centred on the Mediterranean civilizations of ancient Greece and Rome, and the civilizing mission of the British empire as interpreted by Rhodes in the final decade of the nineteenth century. It also speaks to Rhodes's ambition to establish a 'Mediterranean' civilization - meaning a white, Western civilization - at the southern tip of Africa, so unlike tropical Africa with its Mediterranean climate and unique flora.

In the Groote Schuur mansion, in the zoological garden and in the imagined Lion House, Rhodes set out to construct the estate as an exemplary landscape, a landscape filled with forms and symbols. This intention extended well beyond the built environment to include non-human animals and even plant species. Paul Maylam has written about Rhodes's ecological imperialism. Rhodes imported two hundred English songbirds to his estate in the belief that birdsong would restore his health. He said: 'It is my dream to fill my forests with the sounds of all the birds of Oxfordshire and Gloucestershire ... their song is nothing less than the song of civilization' (Maylam 2005, 73). He also imported llamas, fallow deer, kangaroos and grey squirrels, which outcompeted and killed off the indigenous red squirrels. As Maylam writes, 'The nightingales and thrushes died out, the rooks were killed off by carrion crows and the chaffinches were exterminated by the grey squirrels. Only the starlings survived - and, like the squirrel-became the curse of the fruit farmers'. 'Rhodes killed and caged indigenous fauna', Maylam continues. 'He imported exotic animals and transplanted alien trees on African soil' (2005, 156). This last phrase, a reference to one of Rhodes's most enduring legacies on the Groote Schuur estate, is a botanical one. Rhodes had three species of trees planted on his estate: imported English oak trees (Quercus robur, representing England), imported 'Stone pines' (Pinus pinea, also known as Italian Stone pine and Umbrella pine, representing the southern Mediterranean) and the indigenous 'Silver tree' (Leucadendron argenteum). I have argued that, like the idealized architecture of the Lion House and his experiments with animals, this triumvirate of tree species speaks to Rhodes's desire to create a hybrid landscape — not quite Europe, not quite Africa - in which the inheritance of a Western classical tradition was fused with British overlordship and 'the white man's burden' (Shepherd 2020; Shepherd et al. 2018). Contemporary visitors to UCT will find that Stone pines now dominate the landscape, so much so that they have become iconic of the institution. Many of my study abroad students from the United States, raised on images of The Lion King, interpret the Stone pines - with their flat crowns and spreading branches - as authentically African. 
By the 1970s, however, public sentiment had turned against zoos like the Groote Schuur Zoo with its heavy bars and confining enclosures. Ommanney quotes a Miss Joan Cleenwerck in a letter of 21 February 1978, who writes: 'It is shameful to see large cats and monkeys etc., kept in small, confined cells' $(2012,41)$. In the early 1980s, the Groote Schuur Zoo was closed and the animals dispersed. The lions were reportedly sold to a 'canned' hunting operation in Namibia (canned hunting is the practice of hunting doped lions in small enclosures). Shortly after its closure, homeless people moved into the cages. In an attempt to force them out, the Public Works Department, the entity that managed the site, demolished many of the cages and the enclosures and bricked up the entranceways to the rest. Yet the lion's cage, the most obviously monumental structure on the site - and thus the one that signaled its status as 'heritage' - was left untouched and has been sporadically inhabited ever since. In a political history of apartheid, the closure of the Groote Schuur Zoo falls between the seismic events of Soweto 1976 and the township revolts of the mid-1980s. The unintended irony of a situation in which a discourse on animal rights could trump the rights of homeless black bodies seeking shelter feels like a very South African situation. In 1999, the part of the Groote Schuur estate that includes the zoo was incorporated into the Cape Peninsula National Park; at present, the site is overgrown and untended. It exists as an extended site of ruination, an archaeological site covering several hectares on the immediate southern border of the UCT upper campus, about 100 meters from the Centre for African Studies. In my time at UCT, the Groote Schuur Zoo site interested me as liminal space that was almost entirely disregarded but is also somehow key to the broader iconographic landscape. From 2001 onwards, I would take classes of students from the Centre for African Studies to the zoo site as a way of thinking about the entangled legacies of Cecil Rhodes at UCT. In later years, some of these students would go on to be active in \#RMF and \#FMF.

One of the many interesting things about Rhodes as a subject is the intentionality that he brought to shaping his own legacy. As Maylam stresses, 'Rhodes carefully planned and choreographed his own immortalization' (2002, 139). Following Rhodes's death, the conversation turned to how he should be memorialized by others. The original proposal, put forward by Earl Grey, was for a massive statue of Rhodes modelled on the Statue of Liberty to be erected on Signal Hill at the entrance to Cape Town's harbour. But ' $[t]$ his Cape Town was spared,' Maylam writes; 'Instead it got the Rhodes Memorial designed by the imperial architect, Herbert Baker, formally opened in 1912' (2002, 144). Rhodes Memorial is situated on the slope of Devil's Peak slightly above and to the north of the UCT campus. Along with the Groote Schuur Zoo site, it forms part of the immediate memorial landscape of the university and comprises three main parts. At the back, the highest part of the memorial, is a Greek-style temple fronted by columns, which Baker modelled on the temples at Paestum (Figure 3.4).

Baker also cites these temples as a source of inspiration for the Lion House, but in fact it seems clear that he was mentally revisiting the plans for the Lion 


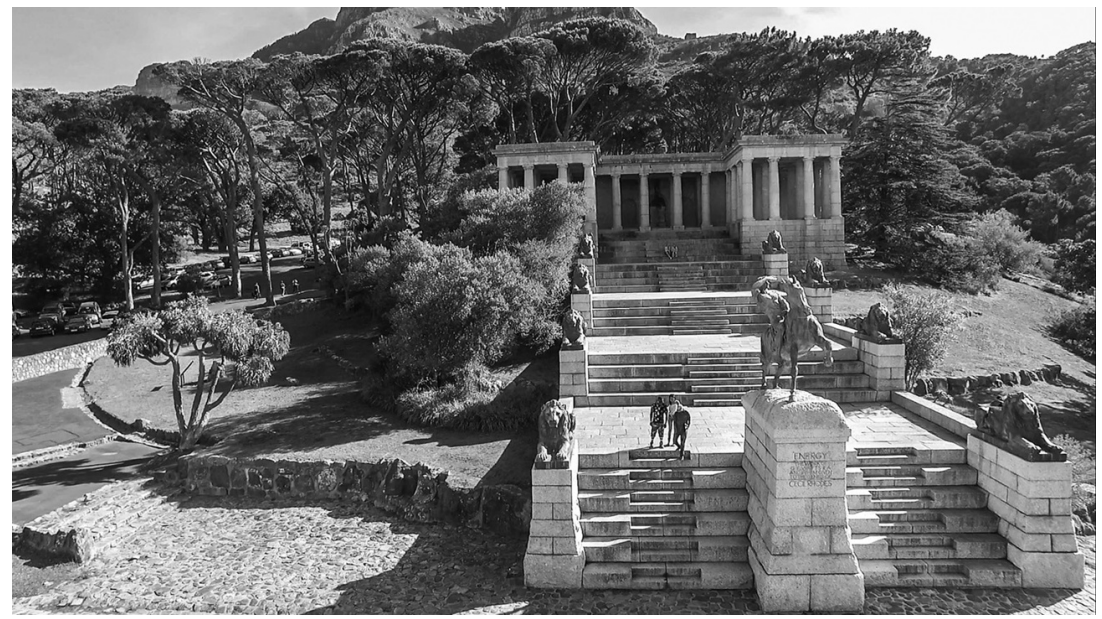

Figure 3.4 Rhodes Memorial, another temple on a hill. Photograph by SkyPixels, used under Wikipedia Creative Commons licence. This file is licenced under the Creative Commons Attribution-Share Alike 4.0 International (https://creativecommons.org/licenses/by-sa/4.0/deed.en) licence.

House in designing Rhodes Memorial. Inside the temple is a bust of Rhodes in contemplative pose modelled by the sculptor J. M. Swan. Shortly after the removal of the Rhodes statue from the UCT campus the bust was modified: the nose was sawed off and an attempt was made to decapitate the bust by sawing through the neck from the back. Imposing steps lead down from the temple and form the second element of the design. At the base of the steps is the statue Physical Energy, the work of the Victorian allegorical artist George Watts. It shows an overscale nude male figure on horseback and manages to be both hyper-masculine and kitsch at the same time (Shepherd 2020). A second casting of Physical Energy now stands in Kensington gardens in London. A third replica was cast in 1957 for the British South Africa Company and unveiled by the Queen Mother in Lusaka, in the then Northern Rhodesia, in 1960. Following the independence of Zambia, a few years later it was taken to the Department of Antiquities in Salisbury, Southern Rhodesia (Harare, Zimbabwe) (Maylam 2002).

On each side of the steps of Rhodes Memorial are four bronze lions, also the work of J. M. Swan. According to Baker, the lions were designed to express 'qualities of calm and reserved strength and power' (Baker 1934, 144), an echo of the 'natural strength and dignity' Rhodes was said to admire about the imagined lions of the Lion House.

The third element of Rhodes Memorial is a semi-circular terrace that offers spectacular views to the north and east, on an axis slightly to the north of the sight lines offered by the Jameson Steps and the university's central plaza. 
Maylam suggests that ' $R$ hodes would have been delighted with the Memorial ... Its prominent site and high visibility gives Rhodes an enormous, looming presence over Cape Town' $(2002,144)$. He notes: 'It is a thoroughly imperial monument, embodying a conjunction of architecture and empire-building' (2002, 144). Rhodes Memorial repeats, in fact serves as the original for, the twin architectural tropes so powerfully deployed by Solomon in the design of the UCT upper campus - the temple on the hill and the site of prospect.

A complex play of references and allusions is thus set up between the three elements that constitute the memorial landscape of UCT. Jameson Hall references the Paestum temple of Rhodes Memorial and is also echoed in the design of the imagined Lion House. The living lions of the Groote Schuur Zoo, meanwhile, are referenced by the bronze lions of Rhodes Memorial. The viewing terrace of Rhodes Memorial is repeated in the central plaza of UCT, which in turn is repeated in the small, semi-circular viewing platform in front of the lion enclosure at the Groote Schuur Zoo (at one point this contained a toposcope, a bronze plaque with directional arrows giving the distance in miles to the principal cities of the British empire). Lines of sight and forms of the gaze are recapitulated from site to site, by multiple agents: the bronze bust of Rhodes in the temple, the figure on horseback, the bronze lions, tourists and sight-seers on the viewing platform of Rhodes Memorial, scholars and students on the central plaza of the university, and the lions of the Groote Schuur Zoo, perched on their grassy knoll in the lion enclosure. At the foremost point of this immense play of signification and crossreference and as a point of focus and intensification was the Rhodes statue of the University of Cape Town, the statue whose presence was understood as such a visceral affront by the student activists of \#RMF (Shepherd 2020).

As I have described it here, the landscape of UCT and the broader landscape of the Groote Schuur estate consist of a dense network of signification and is deeply inscribed with the historical legacy of Cecil Rhodes. The material inscription of Rhodes's legacy takes many forms: architectural form; the organization of space; plant and animal species; archaeological sites and ruins on the landscape; and the more self-conscious making of space through statues and memorials. A final point is that this network of signification once extended across much of southern Africa, encompassing Northern Rhodesia, Southern Rhodesia, Rhodes's burial site in the Valhalla of the Matopos and numerous individual sites, locations, shrines, statues, place names, ceremonies, feast days (like Southern Rhodesia's Founders Day) and so on. With the waning of the British empire, the independence of once-colonized territories and the re-evaluation of Rhodes's legacy, this landscape of memory has been radically contracted to the point where we can speculate that the Groote Schuur estate constitutes the last remaining outpost of Rhodesia (Shepherd 2020). The question that follows for those who are part of this landscape is: What does it mean to dwell figuratively in Rhodesia? 


\section{Spectres of Rhodes}

Following the removal of the Rhodes statue, university managers had the plinth, which remains on the site, covered in a plain wooden box. This was painted grey but was soon graffitied. As I write in late 2020, the boxed plinth remains on the UCT campus. Over the years it has become a site for impromptu demonstrations and performances, like the small installations that are made on the plinth each year on the anniversary of the massacre of mineworkers at Marikana. It also enjoys a certain notoriety. I often see visitors and students posing for selfies in front of the plinth. One of the most eloquent reminders of the Rhodes statue was made shortly before its removal. In late summer the afternoon sun shines from the northwest, behind and to the side of Devil's Peak. Someone carefully traced the outline of the shadow of the Rhodes statue as it was cast on Jameson steps, and then filled this in with black paint. Now the statue is gone, but the shadow most certainly remains (Shepherd 2020).

My theme in this chapter has been the notion of deep inscription. I have argued that the legacy of Cecil Rhodes and the things he stood for-racism, patriarchy, colonialism, imperialism the exploitation of natural worlds - are deeply inscribed in the social, material and intellectual landscape of the Groote Schuur estate and the University of Cape Town. This legacy takes material forms, some of which-like the projection of Rhodes's ideas into plant and animal worlds - are surprising. It also takes less tangible forms: an embodied habitus, forms of the gaze and a certain relationship to knowledge and to broader society. As a kind of shorthand, I have named this landscape of forms and ideas 'Rhodesia'. In a second part of my argument, I have speculated that, dwelling in Rhodesia, one is at best partially and fitfully aware of the nature of this legacy and the many tangled forms it takes. Instead, it forms part of an ambiguous inheritance, handed down to us along with the tools of the disciplines and the norms of the institution.

In concluding, I would like to take this argument through one more step that involves generalizing the case that I present in this chapter. The case of Cecil Rhodes and UCT presents with unusual, and sometimes startling, clarity a certain relationship to coloniality in the institution of the university. There is something phantasmagorical about the story that I unfold. It reads as a kind of fairy tale complete with lions, forests and ogres who brood in temples. However, rather than seeing this as an exceptional case - as UCT tends to see itself - I would argue just the opposite. My argument is that the case of Rhodes and UCT presents with unusual clarity and intensity a set of dynamics and relationships that are a deeply inscribed aspect of the university as institution, wherever the university has a historical relationship to colonial worlds of practice, or slave economies, or is entangled with racism, patriarchy and other forms of patronage and privilege (as, in fact, is the case for most universities in most places). Indeed, I would argue that these relationships and dynamics are part of the ambiguous legacy of institutions in Europe and North America as much as institutions in the Global South like UCT. At the same time, this 
legacy is generally disavowed. For a brief, brilliant moment the activists of \#RMF found a language and a form of protest that was able to haul this legacy into focus. In doing so, I believe that they were aided by the form of the Rhodes statue itself, which so powerfully summarized this deeply inscribed coloniality, as well as by the sheer intensity of the surrounding symbolic and memorial landscape. I would argue that theirs was a brave and singular achievement whose meaning we need to cherish. To argue against systematic forms of disavowal, the disciplinary power of the institution and the very forms of a certain kind of reason is an extraordinary achievement that involves a kind of unlearning as much as a learning (Tlostanova and Mignolo 2012).

Since the moment of \#RMF, things have become more complicated and less clear, as perhaps is inevitable. Reputations have waned, the student movement in South Africa has been internally divided and university managers have seized on the 'crisis' of \#FMF as an opportunity to force through a range of measures: ramped-up security, the militarization and gating of campuses, budget cuts, increased class sizes and random security checks. Some of the \#RMF activists have talked of the emotional and physical toll taken by the events of \#RMF and \#FMF, the protracted struggle with university managers and the danger and insecurity of being exposed to a police presence on campus. In 2017, I left UCT for a position in Denmark, a society that struggles with its own relationship to coloniality. In a strange way, this has given me the distance necessary to think about these things. Cycling through the woods to the pleasant campus at Moesgaard, I think about the abandoned zoo, the Stone pines, the grandeur of Sarah Baartman Hall and the empty plinth and its unsettled history.

\section{Note}

1 This work forms part of the ECHOES project which has received funding from the European Union's Horizon 2020 research and innovation programme under grant agreement No. 770248.

\section{References}

Baker, Herbert. 1934. Cecil Rhodes: By His Architect. London: Oxford University Press.

Bass, Alan. 2002. Difference and Disavowal: The Trauma of Eros. Palo Alto: Stanford University Press.

Claassen, John M. 2009. "Yonder Lies Your Hinterland': Rhodes, Baker and the Twisted Strands of the South African Architectural Tradition." Akroterion 54: 69-86.

Daily Telegraph. 2012. "Beautiful Universities Around the World." 16 August. https:// www.telegraph.co.uk/expat/education-and-family/beautiful-universitiesaround-the-world/.

Fischer, Emma. n.d. "The Groote Schuur." Bright Continent. Accessed 13 December 2018. https://access.thebrightcontinent.org/items/show/29.

Freud, Sigmund. 1923. "The Infantile Genital Organization.” SE XIX XIX (19).: 143-4. 
Maylam, Paul. 2002. "Monuments, Memorials and the Mystique of Empire: The Immortalization of Cecil Rhodes in the Twentieth Century." African Sociological Review 6 (1): 138-47.

Maylam, Paul. 2005. The Cult of Rhodes: Remembering an Imperialist in Africa. Cape Town: David Philip.

Mignolo, Walter. 2007. "Delinking: The Rhetoric of Modernity, the Logic of Coloniality and the Grammar of De-Coloniality." Cultural Studies 21 (2): 449-514.

Mignolo, Walter. 2008. "Coloniality: The Darker Side of Modernity." In Coloniality at Large: Latin America and the Postcolonial Debate, edited by Mabel Moraña, Enrique Dussel, and Carlos A. Jáuregui, 39-49. Durham: Duke University Press.

Mignolo, Walter. 2011. The Darker Side of Western Modernity: Global Futures, Decolonial Options. Durham: Duke University Press.

Mignolo, Walter. 2013. "Geopolitics of Sensing and Knowing: On (De)coloniality, Border Thinking, and Epistemic Disobedience." Confero: Essays on Education, Philosophy and Politics 1 (1): 129-50.

Mudariki, Richard. 2014. "Alone with Strangers." 30 July. http://richardmudariki. blogspot.com/2014/07/alone-with-strangers.html.

Nyamnjoh, Francis B. 2013. \#RhodesMustFall: Nibbling at Resilient Colonialism in South Africa. Bamenda: Langaa Research and Publishing.

Ommanney, Sarah. 2012. Lacuna: Groote Schuur Zoo. Cape Town: Centre for Curating the Archive.

Phillips, Howard. 1993. The University of Cape Town 1918-1948: The Formative Years. Cape Town: UCT Press.

Robins, Steven. 2013. "How Poo Became a Political Issue." IOL, 3 July. https://www. iol.co.za/dailynews/opinion/how-poo-became-a-political-issue-1541126.

Robins, Steven. 2014. "Poo Wars as Matter out of Place: 'Toilets for Africa' in Cape Town." Anthropology Today 30 (1): 1-3.

Shepherd, Nick. 2003. "State of the Discipline: Science, Culture and Identity in South African Archaeology.” Journal of Southern African Studies 29 (4): 823-44.

Shepherd, Nick. 2007. "Archaeology Dreaming; Postapartheid Urban Imaginaries and the Bones of the Prestwich Street Dead." Journal of Social Archaeology 7 (1): $3-28$.

Shepherd, Nick. 2015. The Mirror in the Ground: Archaeology, Photography and the Making of a Disciplinary Archive. Cape Town: Jonathan Ball Publishers and the Centre for Curating the Archive.

Shepherd, Nick. 2017. La Mano del Arqueologo: Ensayos 2001-2015. [The hand of the archaeologist: Essays 2001-2015]. Universidad del Cauca (Colombia), JAS Arqueología (Spain) and Noches Blancas (Argentina).

Shepherd, Nick. 2020. "After the \#Fall: The Shadow of Cecil Rhodes at the University of Cape Town." City: Analysis of Urban Change, Theory, Action 24 (3-4): 565-79.

Shepherd, Nick, Christian Ernsten, and Dirk-Jan Visser. 2018. The Walking Seminar: Embodied Research in Emergent Anthropocene Landscapes. Amsterdam: Reinwardt Academy Press.

Tlostanova, Madina, and Walter Mignolo. 2012. Learning to Unlearn: Decolonial Reflections from Eurasia and the Americas. Columbus: Ohio State University Press.

Twidle, Hedley. 2012. "'All Like and Yet Unlike the Old Country': Kipling in Cape Town, 1891-1908." English in Africa 39 (2): 85-109. 